• 研究报告・

\title{
海南岛西海岸红树林软体动物多样性
}

\author{
马 维 ${ }^{1}$ 王 瑁 $1^{*}$ 王文卿 ${ }^{1}$ 刘 毅 ${ }^{2}$ 罗柳青 ${ }^{1}$ 唐朝艺 ${ }^{1}$ \\ 1 (厦门大学环境与生态学院, 福建厦门 361102) \\ 2 (莆田绿萌滨海湿地研究中心, 福建莆田 351100)
}

\begin{abstract}
摘要: 为了掌握海南岛西海岸红树林软体动物多样性状况, 本文于2015-2016年对海南岛西海岸6个主要红树林分 布区软体动物的种类组成、物种多样性和群落结构的时空变化进行了研究。共采集到软体动物57科201种, 主要优 势种有珠带拟蟹守螺(Cerithidea cingulata)、绯拟沼螺(Assiminea latericea)、圆胖樱蛤(Pinguitellina cycladiformis) 和斜肋齿蜷(Sermyla riqueti)等。年平均密度与平均生物量分别为 $324.13 \mathrm{ind} . / \mathrm{m}^{2}$ 和 $142.88 \mathrm{~g} / \mathrm{m}^{2}$, 物种数、密度和生 物量均高于北部湾沿岸的其他红树林。海南岛西海岸各红树林软体动物的密度和生物量均未呈现明显的季节变化, 软体动物密度存在空间上的显著差异。聚类分析结果显示, 在盐度、土壤结构和红树林群落存在差异的不同红树 林, 软体动物种类组成相似度低。多因子AZTI海洋生物指数(M-AMBI)结果表明海南岛西海岸红树林软体动物群 落未受明显扰动, 生态环境质量介于一般和优良之间, 但仍受到人类活动与外来植物入侵威胁, 因其在候鸟迁徙 中的重要作用, 亟需加强管理与保护。
\end{abstract}

关键词：红树林; 软体动物; 海南岛西海岸; 生物多样性; 北部湾

\section{Biodiversity of mangrove mollusks in the west coast of Hainan Island, China}

\author{
Wei Ma ${ }^{1}$, Mao Wang ${ }^{1 *}$, Wenqing Wang ${ }^{1}$, Yi Liu ${ }^{2}$, Liuqing Luo ${ }^{1}$, Chaoyi Tang ${ }^{1}$ \\ 1 College of the Environment \& Ecology, Xiamen University, Xiamen, Fujian 361102 \\ 2 Putian Green Sprout Coastal Wetlands Research Center, Putian, Fujian 351100
}

\begin{abstract}
We aimed to understand the mollusk community in the mangrove wetlands of the west coast of Hainan Island. To do so, we explored the temporal and spatial variation in species composition, diversity and community structure of mollusks in six mangrove wetlands from 2015 to 2016. We identified a total of 201 mollusk species belonging to 57 families. The dominant species included Cerithidea cingulata, Assiminea latericea, Pinguitellina cycladiformis, and Sermyla riqueti. The average density and biomass of mollusks were 324.13 ind. $/ \mathrm{m}^{2}$ and $142.88 \mathrm{~g} / \mathrm{m}^{2}$, respectively. Observed density, biomass and species richness at west coast of Hainan Island were higher than values recorded in other mangrove wetlands located in the coast of Beibu Gulf. While species richness, density or biomass of mollusks did not vary seasonally, mollusk densities varied spatially in our study. Cluster analysis showed that mangrove wetlands differing in salinity, soil texture and mangrove communities had very dissimilar mollusk communities. The multivariate-AZTI marine biotic index (M-AMBI) value suggested that the mollusk communities of mangrove wetlands located in the west coast of Hainan Island were undisturbed. Although the benthic community was reasonably healthy, they were nevertheless negatively impacted by human activities and invasion of exotic plants. Given that mollusks are important for various bird species that migrate to Hainan Island, we recommend measures such as pollution control and in situ conservation to help preserve the biodiversity of mangrove mollusks in the west coast of Hainan Island.
\end{abstract}

Key words: mangrove; mollusk; west coast of Hainan Island; biodiversity; Beibu Gulf 
红树林是生长在热带与亚热带海湾、河口潮间 带滩涂上特有的木本植物群落, 处于陆地与海洋的 过渡区域(林鹏, 1997)。它通过输出大量调落物和植 物群落自身的屏蔽作用, 为鸟类和底栖动物提供稳 定的繁殖发育场所, 有重要的生态与经济价值(Barbier et al, 2011)。软体动物作为红树林生态系统重要 的组成部分, 通过摄食沉积物和植物组织促进养分 循环(Kristensen et al, 2008), 并作为食物网的一环, 成为包括鸟类在内的脊椎动物捕食者主要的食物 来源(Zou et al, 2008), 是红树林生态系统中物质循 环和能量流动重要的消费者与转移者。包括软体动 物在内的底栖生物对环境变化十分敏感(王瑁等, 2013), 是海洋沉积环境生物监测中灵敏的指示生 物(蔡立哲, 2015), 可以反映红树林的环境特点并指 示生态环境质量。

海南岛西海岸位于北部湾东侧, 与广西和广东 雷州半岛环抱北部湾。东方市的四必湾、儋州市的 儋州湾、临高县的新盈湾和马受湾、澄迈县的花场 湾等地分布有 942.69 ha 的红树林, 约占海南岛 4,736.05 ha红树林面积的20\% (但新球等, 2016)。与 东海岸相比, 海南岛西海岸红树林的植物种类组成 较简单, 但其生态功能不容忽视, 根据海南观鸟会 的记录, 新盈湾和四必湾红树林湿地是勺嘴劀 (Calidris pygmaea)和黑脸琵嘼(Platalea minor)等多 种濒危候鸟重要的补给站和越冬地(Yu et al, 2018)。 目前对海南岛西海岸红树林的基本情况了解甚少, 红树林的保护、管理和开发缺乏最基本的科学依据 (王文卿和王瑁, 2007)。北部湾沿岸广西和广东雷州 半岛红树林软体动物生物多样性已经有了较详细 的资料(赖廷和与何斌源, 1998; 韩维栋等, 2003; 唐 以杰和余世孝, 2007), 而对海南岛西海岸红树林软 体动物的研究较少, 仅是在部分地点进行了零星的 调查(张光星等, 2016)。2017年国务院批复同意建设 北部湾城市群, 目标是统筹自然岸线利用与海陆生 态资源环境保护, 确立起蓝色海湾生态格局。海南 岛西海岸作为北部湾重要的组成部分, 对红树林生 物多样性及其生态本底的调研, 将为我国北部湾城 市群开发战略提供科学依据。

本文选取海南岛西海岸6个主要的红树林分布 区: 东方市四必湾、儋州市儋州湾、儋州市峨蔓镇 盐丁、临高县新盈湾、临高县马衰湾和澄迈县花场 湾为调查对象, 这 6 个地点的红树林面积占海南岛
西海岸红树林总面积的 $90 \%$ 以上。选取代表性断面， 采用样方法结合定性调查，比较不同地点旱、雨季 间软体动物群落结构差异, 讨论红树林软体动物时 空分布与红树植物群落组成以及环境因子的关系, 并与北部湾其他区域进行对比，从软体动物角度整 体评估环北部湾区域海岸带生态现状。

\section{材料与方法}

\section{1 研究区域与取样方法}

2015年8月(雨季)和2016年1月(旱季), 对海南 岛西海岸6个主要红树林分布区的软体动物多样性 进行调查(图1)。各调查地点主要红树林群落、土壤 粒径及间隙水盐度见表 1 。根据植物群落类型、大 型地貌和人为干扰情况, 分别在四必湾(S1、S2)与 花场湾(S15、S16)各设置2条断面，儋州湾(S3、S4、 $\mathrm{S} 5)$ 、盐丁 (S6、S7、S8)、新盈湾(S9、S10、S11)和 马衰湾(S12、S13、S14)各设置3条断面，共16条断 面。在每个断面设置红树林林内和林外光滩 2 个采 样站点, 每个站点用 $25 \mathrm{~cm} \times 25 \mathrm{~cm}$ 的定量框随机取 5 个样方(样方间距 $10 \mathrm{~m}$ 以上), 收集表面的软体动 物，挖至 $30 \mathrm{~cm}$ 深，使用 $1 \mathrm{~mm}$ 孔径的篎网分选出泥 样中的软体动物。在每个断面的林内站点, 设置3 个 $3 \mathrm{~m} \times 3 \mathrm{~m}$ 的样方, 收集所有的树栖软体动物。与 此同时，对调查区域树上、底表及底内生活的所有 软体动物进行定性调查。所收集软体动物样品的处

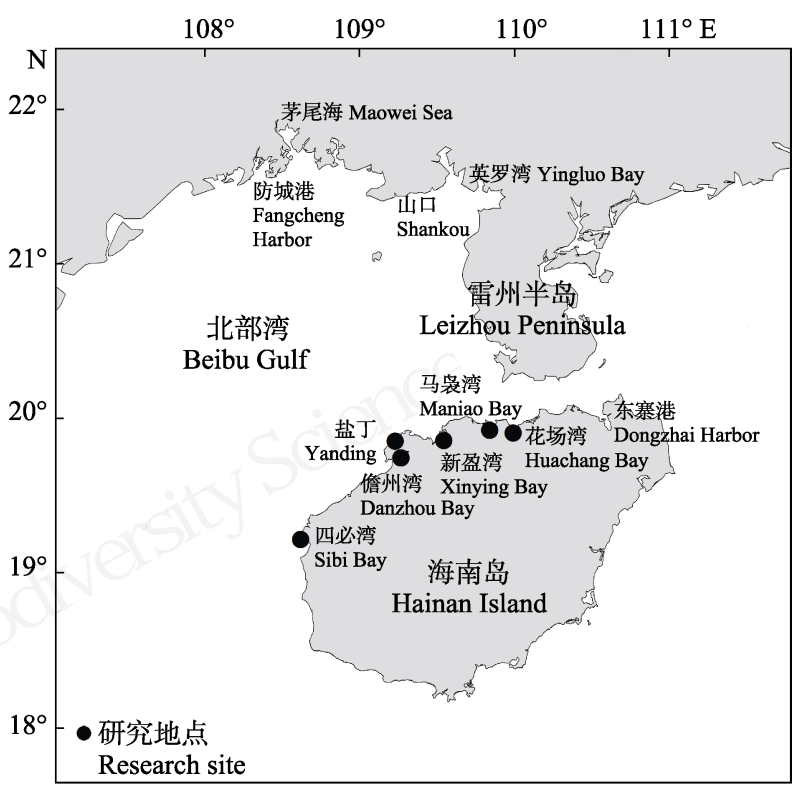

图1 海南岛西海岸调查地点分布图

Fig. 1 Survey area in the west coast of Hainan Island 
表1 海南岛西海岸红树林群落及环境特征

Table 1 Mangrove communities and environmental factors of research sites in the west coast of Hainan Island

\begin{tabular}{|c|c|c|c|}
\hline 调查地点 Research sites & $\begin{array}{l}\text { 主要红树林群落 } \\
\text { Main mangrove community }\end{array}$ & 土壤质地 Soil texture & $\begin{array}{l}\text { 间隙水盐度 } \\
\text { Salinity of interstitial } \\
\text { water (\%o) }\end{array}$ \\
\hline 东方市四必湾 Sibi Bay, Dongfang City & 白骨壤群落 Avicennia marina community & 粉砂质壤土 Silty loam & 31.0 \\
\hline $\begin{array}{l}\text { 儋州市儋州湾 } \\
\text { Danzhou Bay, Danzhou City }\end{array}$ & $\begin{array}{l}\text { 红海榄群落 Rhizophora stylosa community } \\
\text { 白骨壤群落 Avicennia marina community }\end{array}$ & 砂质壤土 Sandy loam & 21.0 \\
\hline 儋州市盐丁 Yanding, Danzhou City & 红海榄群落 Rhizophora stylosa community & 粉砂质粘壤土 Silty clay loam & 27.4 \\
\hline $\begin{array}{l}\text { 临高县新盈湾 } \\
\text { Xinying Bay, Lingao County }\end{array}$ & $\begin{array}{l}\text { 红海榄群落 Rhizophora stylosa community } \\
\text { 白骨壤群落 Avicennia marina community }\end{array}$ & 砂质壤土 Sandy loam & 25.5 \\
\hline $\begin{array}{l}\text { 临高县马裏湾 } \\
\text { Maniao Bay, Lingao County }\end{array}$ & 桐花树群落 Aegiceras corniculatum community & 壤土 Loam & 13.2 \\
\hline $\begin{array}{l}\text { 澄迈县花场湾 } \\
\text { Huachang Bay, Chengmai County }\end{array}$ & $\begin{array}{l}\text { 红海榄群落 Rhizophora stylosa community } \\
\text { 桐花树群落 Aegiceras corniculatum community } \\
\text { 白骨壤群落 Avicennia marina community }\end{array}$ & 砂质壤土 Sandy loam & 15.7 \\
\hline
\end{tabular}

理、鉴定、计数和称量均按《海洋调查规范 第6部 分: 海洋生物调查指南》(GB/T 12763.6-2007)进行。

\section{2 数据处理与分析}

软体动物优势度与多样性指数采用如下指标 进行计算:

优势度指数(徐兆礼和陈亚篧, 1989):

$$
Y=P_{i} \times f_{i}
$$

Margalef物种丰富度指数(Margalef, 1968):

$d=(S-1) / \log _{2} N$

Shannon-Wiener多样性指数 (Shannon \& Weaver, 1949):

$$
H^{\prime}=-\sum_{i=1}^{S} P_{i} \log _{2} P_{i}
$$

Pielou均匀度指数(Pielou, 1975):

$$
J=H / \log _{2} S
$$

式中, $P_{i}$ 是物种 $i$ 的个体数与总个体数的比值; $f_{i}$ 为物 种 $i$ 在各站位出现的频率; $S$ 为样方内的总物种数; $N$ 为样方内所有物种的总个体数。当 $Y \geq 0.02$ 时, 该种 确定为优势种(徐兆礼和陈亚翟, 1989)。

使用SPSS 18.0进行双因素方差分析, 比较软 体动物密度、生物量、多样性指数、AZTI海洋生物 指数 (AMBI) 以及多因子 AZTI 海洋生物指数 $(\mathrm{M}-\mathrm{AMBI})$ 在不同地点和季节间的差异。软体动物 群落种类组成分析基于物种密度, 使用 PRIMER 5.0 将密度数据经四次方根转换、标准化处理后计算 断面间的Bray-Curtis相似性系数, 并以组平均法进 行等级聚类。
使用AMBI 5.0计算AMBI和M-AMBI值, 软体 动物的生态分组(ecological group, EG)根据软件自 带的分组表进行, 分组表中未包含的物种则划入表 中存在的上级分类单元，其中，对扰动敏感的物种 分入 EG I, 对扰动不敏感的物种分入 EG II, 对扰动 有耐受力的物种分入EG III, EG IV为第二机会种, EG V为第一机会种。生态质量分级标准参考蔡立哲 等 (2011) 分为高等 (high)、优 良 (good)、一般 (moderate)、较差(poor)、恶劣(bad), 其中M-AMBI 值分别为 $>0.82 、 0.62-0.82 、 0.41-0.62 、 0.20-0.40$ 、 $<0.20$; AMBI值分别为 < $1.2 、 1.2-3.3 、 3.3-5.0$ 、 5.0-6.0、Azoic (无生命), 对应的扰动等级分别为无 扰动、轻度扰动、中度干扰、重度扰动和极端扰动 (Pinto et al, 2009)。

\section{2 结果}

\section{1 物种组成与优势种}

在海南岛西海岸红树林共采集到软体动物 2 纲 13目57科201种(附录1), 其中双壳纲7目30科114种, 占总种类数的 $56.7 \%$, 腹足纲 6 目 27 科 87 种, 占 $43.3 \%$ 。宋蛤科的种类最多, 共30种, 其次是耳螺科, 共13种。绝大部分软体动物为典型的海水型种类和 河口型种类, 此外还有少量的陆生型种类和淡水型 种类。陆生型种类有扁蜗牛(Bradybaena similaris)、 褐云玛瑙螺(Achatina fulica) 和部分耳螺科种类, 淡 水型种类有大瓶螺(Pomacea canaliculata)、斜肋齿 蜷(Sermyla riqueti)、瘤拟黑螺(Melanoides tuberculata) 
和河蚬(Corbicula fluminea)等。褐云玛瑙螺和大瓶 螺被列入中国外来入侵物种第一批名单，萨氏仿贻 贝(Mytilopsis sallei)也是已经确认的入侵种。

6 个调查地点中, 四必湾的种类数最多(131种), 马白湾、盐丁和花场湾的较少, 分别为46、58和 61 种，儋州湾有 98 种，新盈湾有 85 种。雨季记录 13 目 51科183种，多于旱季的 13 目 55 科137种，不同地点 旱、雨季软体动物种类数见图 2 。

海南岛西海岸红树林软体动物的优势种在不 同地点间存在明显差异(表2)。总体来看优势种以蜒 螺科、拟沼螺科、蚬科、汇螺科和黑螺科的种类居 多, 四必湾和儋州湾的林外光滩分布有较多的珠带

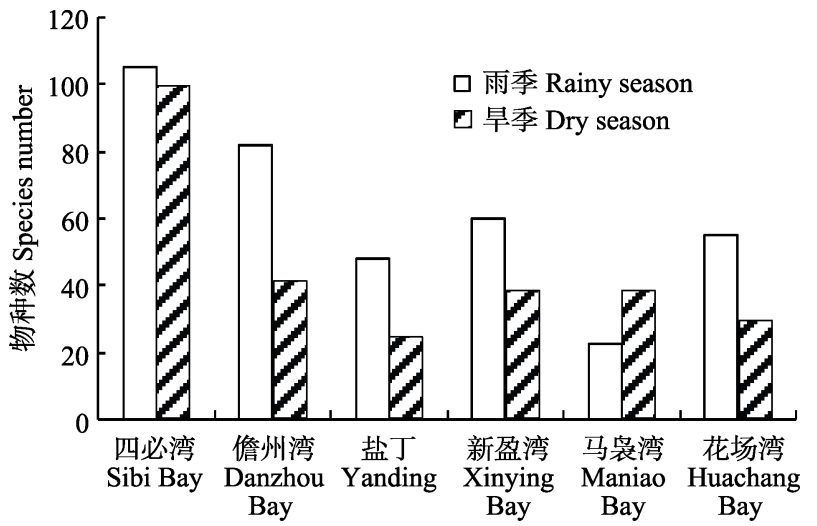

图2 海南岛西海岸红树林软体动物的物种数

Fig. 2 Species number of mangrove mollusk in the west coast of Hainan Island

表2 海南岛西海岸红树林软体动物优势种指数值(优势种为加粗斜体数字对应的种类)

Table 2 Values of dominance index of mangrove mollusks in the west coast of Hainan Island. Dominant species were marked with bold italic.

\begin{tabular}{|c|c|c|c|c|c|c|c|c|c|c|c|c|}
\hline \multirow[t]{2}{*}{$\begin{array}{l}\text { 种类 } \\
\text { Species }\end{array}$} & \multicolumn{2}{|c|}{$\begin{array}{l}\text { 四必湾 } \\
\text { Sibi Bay }\end{array}$} & \multicolumn{2}{|c|}{$\begin{array}{l}\text { 儋州湾 } \\
\text { Danzhou Bay } \\
\end{array}$} & \multicolumn{2}{|c|}{$\begin{array}{l}\text { 盐丁 } \\
\text { Yanding } \\
\end{array}$} & \multicolumn{2}{|c|}{$\begin{array}{l}\text { 新盈湾 } \\
\text { Xinying Bay }\end{array}$} & \multicolumn{2}{|c|}{$\begin{array}{l}\text { 马興湾 } \\
\text { Maniao Bay }\end{array}$} & \multicolumn{2}{|c|}{$\begin{array}{l}\text { 花场湾 } \\
\text { Huachang Bay }\end{array}$} \\
\hline & $\begin{array}{l}\text { 雨季 } \\
\text { Rainy } \\
\text { season }\end{array}$ & $\begin{array}{l}\text { 旱季 } \\
\text { Dry } \\
\text { season }\end{array}$ & $\begin{array}{l}\text { 雨季 } \\
\text { Rainy } \\
\text { season }\end{array}$ & $\begin{array}{l}\text { 旱季 } \\
\text { Dry } \\
\text { season }\end{array}$ & $\begin{array}{l}\text { 雨季 } \\
\text { Rainy } \\
\text { season }\end{array}$ & $\begin{array}{l}\text { 旱季 } \\
\text { Dry } \\
\text { season }\end{array}$ & $\begin{array}{l}\text { 雨季 } \\
\text { Rainy } \\
\text { season }\end{array}$ & $\begin{array}{l}\text { 旱季 } \\
\text { Dry } \\
\text { season }\end{array}$ & $\begin{array}{l}\text { 雨季 } \\
\text { Rainy } \\
\text { season }\end{array}$ & $\begin{array}{l}\text { 旱季 } \\
\text { Dry } \\
\text { season }\end{array}$ & $\begin{array}{l}\text { 雨季 } \\
\text { Rainy } \\
\text { season }\end{array}$ & $\begin{array}{l}\text { 旱季 } \\
\text { Dry } \\
\text { season }\end{array}$ \\
\hline $\begin{array}{l}\text { 才聚牡蚛 } \\
\text { Saccostrea glomerata }\end{array}$ & 0.006 & 0.000 & - & 0.002 & 0.114 & 0.002 & 0.005 & 0.003 & - & - & 0.000 & 0.001 \\
\hline $\begin{array}{l}\text { 台湾朽叶蛤 } \\
\text { Coecella formaosae }\end{array}$ & - & - & - & - & - & 0.063 & - & - & - & - & - & - \\
\hline $\begin{array}{l}\text { 圆胖樱蛤 } \\
\text { Pinguitellina cycladiformis }\end{array}$ & - & - & - & - & - & 0.003 & 0.842 & 0.714 & - & - & - & 0.000 \\
\hline $\begin{array}{l}\text { 拟箱美丽蛤 } \\
\text { Merisca capsoides }\end{array}$ & - & - & - & - & 0.050 & 0.003 & 0.061 & 0.001 & - & - & - & - \\
\hline 红树蚬 Geloina coaxans & - & - & - & 0.048 & - & - & 0.001 & 0.001 & 0.001 & 0.007 & 0.050 & 0.020 \\
\hline 豆彩螺 Clithon faba & - & - & - & - & - & 0.333 & - & - & - & 0.006 & 0.001 & - \\
\hline $\begin{array}{l}\text { 奥莱彩螺 } \\
\text { Clithon oualaniensis }\end{array}$ & 0.045 & 0.012 & 0.010 & - & - & 0.003 & - & - & 0.009 & - & - & - \\
\hline 斜肋齿蜷 Sermyla riqueti & - & - & 0.111 & 0.001 & - & - & - & - & 0.267 & 0.713 & 0.455 & 0.349 \\
\hline $\begin{array}{l}\text { 短拟沼螺 } \\
\text { Assiminea brevicula }\end{array}$ & 0.058 & 0.014 & 0.065 & - & - & - & - & 0.014 & 0.000 & 0.002 & 0.003 & 0.011 \\
\hline $\begin{array}{l}\text { 绯拟沼螺 } \\
\text { Assiminea latericea }\end{array}$ & - & 0.005 & 0.161 & 0.070 & - & - & 0.001 & 0.167 & 0.000 & 0.052 & 0.001 & 0.009 \\
\hline $\begin{array}{l}\text { 古氏滩栖螺 } \\
\text { Batillaria cumingii }\end{array}$ & - & - & - & 0.024 & - & - & - & - & - & - & - & - \\
\hline $\begin{array}{l}\text { 尖雉拟蟹守螺 } \\
\text { Cerithidea largillierti }\end{array}$ & 0.025 & - & - & - & - & - & - & - & - & - & - & - \\
\hline $\begin{array}{l}\text { 小翼拟蟹守螺 } \\
\text { Cerithidea microptera }\end{array}$ & 0.003 & 0.098 & 0.017 & - & - & 0.008 & - & - & - & - & - & - \\
\hline $\begin{array}{l}\text { 桑切氏两栖螺 } \\
\text { Salinator sanchezi }\end{array}$ & 0.027 & 0.030 & - & - & - & - & - & - & - & - & - & - \\
\hline
\end{tabular}

- 未出现 Not present. 
拟蟹守螺(Cerithidea cingulata), 林内则主要是拟沼 螺科的短拟沼螺 (Assiminea brevicula) 和绯拟沼螺(A. latericea); 新盈湾采集到大量的圆胖樱蛤(Pinguitellina cycladiformis), 成群地分布在林外光滩; 斜肋齿 蜷是马裒湾和花场湾的第一优势种，马裒湾还分布 有大量的花蚬(Cyrenodonax formosana), 是雨季的 第一优势种; 盐丁由于在雨季采集到的个体数较少, 导致旱、雨季调查的优势种组成存在较大差异, 除盐 丁外其他地点优势种组成季节差异不明显(表2)。

\section{2 密度和生物量}

海南岛西海岸红树林软体动物的年平均密度 和平均生物量分别为 324.13 ind. $/ \mathrm{m}^{2}$ 和 $142.88 \mathrm{~g} / \mathrm{m}^{2}$ 。 双因素方差分析结果显示, 软体动物年平均密度在 不同地点间存在极显著差异 $(P<0.001)$, 马哀湾的 年平均密度显著高于儋州湾、新盈湾和盐丁。软体 动物年平均生物量在不同地点之间差异不显著 $(P=$
$0.111)$ 。从季节上看, 软体动物年平均密度 $(P=$ $0.780)$ 和生物量 $(P=0.960)$ 旱、雨季间均不存在显著 性差异，同一地点软体动物的密度和生物量在旱、 雨季间波动变化不大(图3)。地点与季节间不存在明 显的交互作用(表3)。

\section{3 种类多样性}

海南岛西海岸红树林软体动物多样性指数见 图4, 地点的丰富度指数 $(d)$ 变化范围为 $0.578-2.706$, 均匀度指数 $(J)$ 的变化范围为 $0.261-0.639$, 多样性指 数 $\left(H^{\prime}\right)$ 的变化范围为1.013-3.038。地点间比较可看 出, 儋州湾物种丰富度指数 $(d)$ 与多样性指数 $\left(H^{\prime}\right)$ 最 高, 均匀度指数 $(J)$ 也处在较高水平, 其软体动物种 类多样性指数最高, 四必湾和花场湾次之, 新盈湾 和马烃湾软体动物种类多样性较低, 盐丁雨季的软 体动物种类多样性最低。

基于站位多样性指数进行双因素方差分析，物
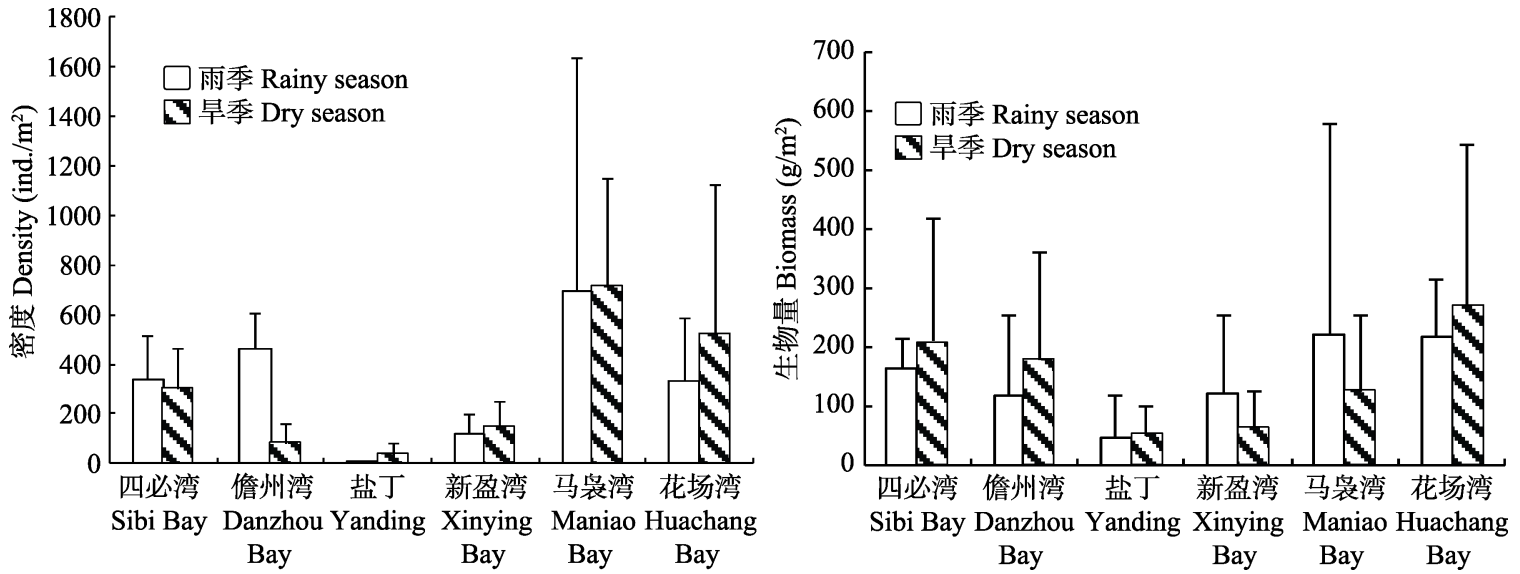

图3 海南岛西海岸红树林软体动物的密度和生物量

Fig. 3 Density and biomass of mangrove mollusk in the west coast of Hainan Island

表3 海南岛西海岸红树林软体动物群落参数的双因素方差校验分析结果

Table 3 Results of two-way ANOVA on mangrove mollusk community parameters in the west coast of Hainan Island

\begin{tabular}{|c|c|c|c|c|c|c|}
\hline \multirow[t]{2}{*}{$\begin{array}{l}\text { 参数 } \\
\text { Parameters }\end{array}$} & \multicolumn{2}{|c|}{ 地点 Site } & \multicolumn{2}{|c|}{ 季节 Season } & \multicolumn{2}{|c|}{$\begin{array}{l}\text { 地点 } \times \text { 季节 } \\
\text { Site } \times \text { Season }\end{array}$} \\
\hline & $F$ & $P$ & 3 & $P$ & $F$ & $P$ \\
\hline 平均密度 Average density & 5.085 & $0.000^{* * *}$ & 0.079 & 0.780 & 0.743 & 0.595 \\
\hline 平均生物量 Average biomass & 1.898 & 0.111 & 0.003 & 0.960 & 0.442 & 0.817 \\
\hline Margalef丰富度指数 Margalef species richness index (d) & 2.068 & 0.087 & 1.923 & 0.172 & 0.417 & 0.835 \\
\hline Shannon-Wiener多样性指数 Shannon-Wiener diversity index $\left(H^{\prime}\right)$ & 5.878 & $0.000^{* * *}$ & 8.001 & $0.007^{* *}$ & 3.276 & $0.012^{*}$ \\
\hline Pielou均匀度指数 Pielou evenness index $(J)$ & 2.065 & 0.087 & 11.175 & $0.002^{* *}$ & 3.148 & $0.016^{*}$ \\
\hline AZTI海洋生物指数 AZTI marine biotic index (AMBI) & 2.844 & $0.024^{*}$ & 0.859 & 0.358 & 3.996 & $0.004^{*}$ \\
\hline 多因子AZTI海洋生物指数 Multivariate-AZTI marine biotic index (M-AMBI) & 10.962 & $0.000^{* * *}$ & 7.369 & $0.009^{* *}$ & 5.251 & $0.000^{* * *}$ \\
\hline
\end{tabular}

$* P<0.05 ; * * P<0.01 ; * * * P<0.001$. 

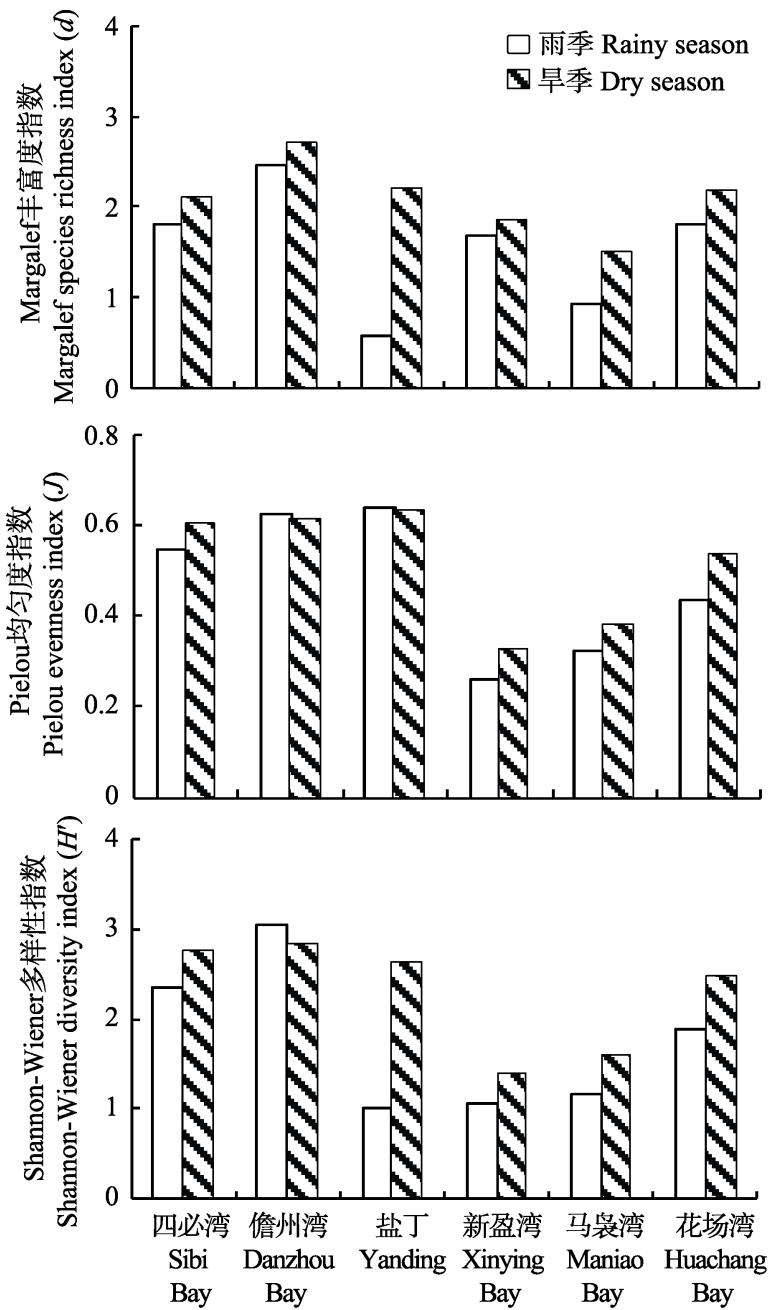

图4 海南岛西海岸红树林软体动物群落多样性指数

Fig. 4 Diversity indices for mangrove mollusk communities in the west coast of Hainan Island

种丰富度指数 $(d)$ 在地点与季节间差异均不显著。多 样性指数 $\left(H^{\prime}\right)$ 在四必湾、花场湾和儋州湾显著大于 马受湾、新盈湾和盐丁, 旱季显著大于雨季。均匀
度指数 $(J)$ 盐丁显著高于其他地点, 四必湾均匀度也 较高, 旱季显著大于雨季。

\section{4 聚类分析}

聚类结果表明(图5), 海南岛西海岸不同红树 林软体动物相似度较低。在相似性系数61-65间作 等级线I，可看出相同地点的样品以较高的相似水 平分为旱、雨季两群, 划分结果表明群组与季节和 地点密切相关; 在相似性系数47-50间作等级线II, 不同断面的样品分地点划归成群，地点间差异大于 季节差异; 在相似性系数8-10间作等级线III, 盐丁 断面样品单独成群, 受土壤粒径小的影响, 软体动 物种类少, 与其他地点相似性较低。

\subsection{AZTI海洋生物指数(AMBI)和多因子AZTI海} 洋生物指数(M-AMBI)

定量调查采集到的 77 种软体动物中，只有 10 种 (12.99\%)可以直接登录到AMBI列表中, 经过重新 分组, 把分组表中未包含的物种划入存在的上级分 类单元，共56种(72.73\%)被分入了相应的生态组别， 未能分组的物种主要包括红树林特有种，以及一些 中国的地方种。从未分组物种占总体密度的比例来 看，除马自湾的雨季(70.1\%)外，其余地点均小于 $20 \%$ (0-19\%), 可以使用AMBI和M-AMBI指数进行 分析。

AMBI 评价结果显示 (表 4), 盐丁与儋州湾 AMBI值较高, 说明这两个地点所受扰动较其他地 点更大。AMBI值在季节间差异不显著。

M-AMBI生态环境状况评价结果显示(表4), 盐 丁的软体动物生态环境质量显著低于其他地点, 新 盈湾和马白湾的软体动物生态环境质量也较低，旱 季显著高于雨季。

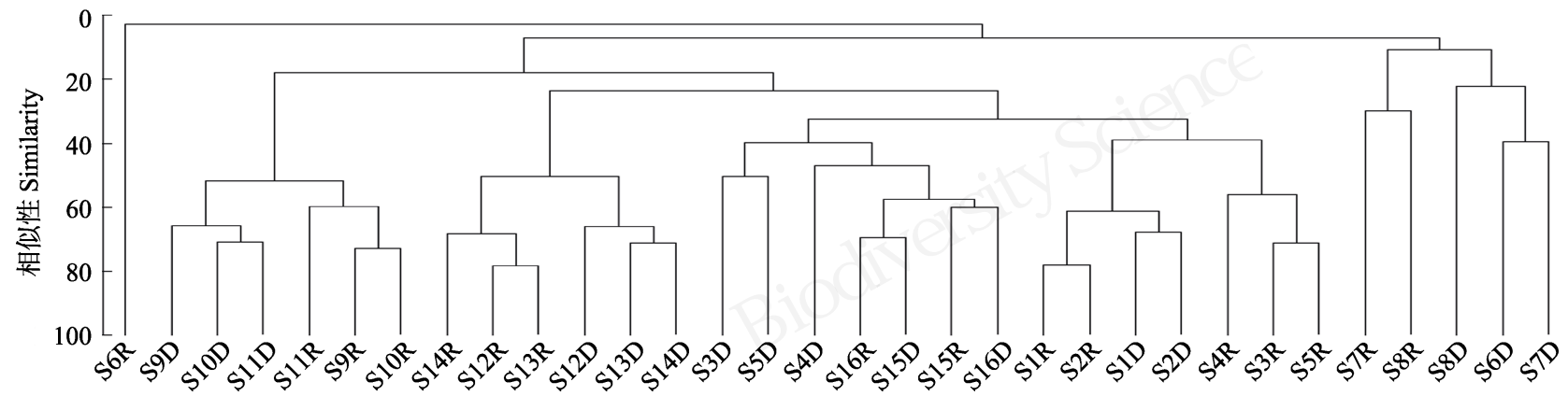

图5 海南岛西海岸红树林软体动物的群落聚类图(S1-S16: 断面; R: 雨季; D: 旱季)

Fig. 5 Cluster dendrogram for mangrove mollusk communities in the west coast of Hainan Island. S1-S16, Transects; R, Rainy season; D, Dry season. 
表4 海南岛西海岸红树林软体动物的AZTI海洋生物指数(AMBI)和多因子AZTI海洋生物指数(M-AMBI)

Table 4 Results of AMBI and M-AMBI for each sites in the west coast of Hainan Island

\begin{tabular}{|c|c|c|c|c|c|c|c|c|c|c|}
\hline 站位 Sites & $\begin{array}{l}\text { 生态分组I } \\
\text { EG I (\%) }\end{array}$ & $\begin{array}{l}\text { 生态分组II } \\
\text { EG II (\%) }\end{array}$ & $\begin{array}{l}\text { 生态分组III } \\
\text { EG III (\%) }\end{array}$ & $\begin{array}{l}\text { 生态分组IV } \\
\text { EG IV (\%) }\end{array}$ & $\begin{array}{l}\text { 生态分组V } \\
\text { EG V (\%) }\end{array}$ & $\begin{array}{l}\text { 未分配率 } \\
\text { Not } \\
\text { assigned (\%) }\end{array}$ & $\begin{array}{l}\text { Mean } \\
\text { AMBI }\end{array}$ & $\begin{array}{l}\text { 扰动等级 } \\
\text { Disturbance } \\
\text { classification }\end{array}$ & M-AMBI & $\begin{array}{l}\text { 状态 } \\
\text { Status }\end{array}$ \\
\hline \multicolumn{11}{|c|}{ 雨季 Rainy season } \\
\hline $\begin{array}{l}\text { 四必湾 } \\
\text { Sibi Bay }\end{array}$ & 83.0 & 16.7 & 0.0 & 0.3 & 0.0 & 6.8 & 0.296 & $\begin{array}{l}\text { 无干扰 } \\
\text { Undisturbed }\end{array}$ & 0.708 & $\begin{array}{l}\text { 优良 } \\
\text { Good }\end{array}$ \\
\hline $\begin{array}{l}\text { 儋州湾 } \\
\text { Danzhou Bay }\end{array}$ & 57.8 & 42.0 & 0.0 & 0.2 & 0.0 & 2.3 & 0.719 & $\begin{array}{l}\text { 无干扰 } \\
\text { Undisturbed }\end{array}$ & 0.697 & $\begin{array}{l}\text { 优良 } \\
\text { Good }\end{array}$ \\
\hline $\begin{array}{l}\text { 盐丁 } \\
\text { Yanding }\end{array}$ & 100.0 & 0.0 & 0.0 & 0.0 & 0.0 & 0.0 & 3.500 & $\begin{array}{l}\text { 中度干扰 } \\
\text { Moderately } \\
\text { disturbed }\end{array}$ & 0.134 & $\begin{array}{l}\text { 恶劣 } \\
\text { Bad }\end{array}$ \\
\hline $\begin{array}{l}\text { 新盈湾 } \\
\text { Xinying Bay }\end{array}$ & 98.5 & 0.8 & 0.7 & 0.0 & 0.0 & 0.5 & 0.045 & $\begin{array}{l}\text { 无干扰 } \\
\text { Undisturbed }\end{array}$ & 0.532 & $\begin{array}{l}\text { 一般 } \\
\text { Moderate }\end{array}$ \\
\hline $\begin{array}{l}\text { 马裹湾 } \\
\text { Maniao Bay }\end{array}$ & 97.4 & 0.8 & 0.0 & 1.8 & 0.0 & 70.1 & 0.136 & $\begin{array}{l}\text { 无干扰 } \\
\text { Undisturbed }\end{array}$ & 0.514 & $\begin{array}{l}\text { 一般 } \\
\text { Moderate }\end{array}$ \\
\hline $\begin{array}{l}\text { 花场湾 } \\
\text { Huachang Bay }\end{array}$ & $y^{97.0}$ & 2.0 & 0.0 & 1.0 & 0.0 & 7.3 & 0.092 & $\begin{array}{l}\text { 无干扰 } \\
\text { Undisturbed }\end{array}$ & 0.639 & $\begin{array}{l}\text { 优良 } \\
\text { Good }\end{array}$ \\
\hline \multicolumn{11}{|c|}{ 旱季 Dry season } \\
\hline $\begin{array}{l}\text { 四必湾 } \\
\text { Sibi Bay }\end{array}$ & 86.4 & 13.6 & 0.0 & 0.0 & 0.0 & 15.7 & 0.348 & $\begin{array}{l}\text { 无干扰 } \\
\text { Undisturbed }\end{array}$ & 0.679 & $\begin{array}{l}\text { 优良 } \\
\text { Good }\end{array}$ \\
\hline $\begin{array}{l}\text { 儋州湾 } \\
\text { Danzhou Bay }\end{array}$ & 69.3 & 29.0 & 0.0 & 1.7 & 0.0 & 18.8 & 0.899 & $\begin{array}{l}\text { 无干扰 } \\
\text { Undisturbed }\end{array}$ & 0.616 & $\begin{array}{l}\text { 一般 } \\
\text { Moderate }\end{array}$ \\
\hline $\begin{array}{l}\text { 盐丁 } \\
\text { Yanding }\end{array}$ & 90.4 & 9.6 & 0.0 & 0.0 & 0.0 & 19.0 & 0.223 & $\begin{array}{l}\text { 无干扰 } \\
\text { Undisturbed }\end{array}$ & 0.557 & $\begin{array}{l}\text { 一般 } \\
\text { Moderate }\end{array}$ \\
\hline $\begin{array}{l}\text { 新盈湾 } \\
\text { Xinying Bay }\end{array}$ & 76.9 & 22.6 & 0.5 & 0.0 & 0.0 & 0.8 & 0.528 & $\begin{array}{l}\text { 无干扰 } \\
\text { Undisturbed }\end{array}$ & 0.550 & $\begin{array}{l}\text { 一般 } \\
\text { Moderate }\end{array}$ \\
\hline $\begin{array}{l}\text { 马呂湾 } \\
\text { Maniao Bay }\end{array}$ & 85.9 & 9.7 & 0.0 & 4.3 & 0.0 & 13.8 & 0.507 & $\begin{array}{l}\text { 无干扰 } \\
\text { Undisturbed }\end{array}$ & 0.601 & $\begin{array}{l}\text { 一般 } \\
\text { Moderate }\end{array}$ \\
\hline $\begin{array}{l}\text { 花场湾 } \\
\text { Huachang Bay }\end{array}$ & $\begin{array}{l}90.2 \\
y\end{array}$ & 7.0 & 0.0 & 2.8 & 0.0 & 4.3 & 0.501 & $\begin{array}{l}\text { 无干扰 } \\
\text { Undisturbed }\end{array}$ & 0.775 & $\begin{array}{l}\text { 优良 } \\
\text { Good }\end{array}$ \\
\hline
\end{tabular}

\section{3 讨论}

\section{1 海南岛西海岸红树林软体动物种类分布}

海南岛西海岸红树林共采集到软体动物2纲13 目57科201种, 种类数比张光星等(2016)调查的结果 有明显增加。优势种以蜒螺科、拟沼螺科、蚬科、 汇螺科和黑螺科的种类居多, 有些种类为不同红树 林的共有优势种, 如奥莱彩螺(Clithon oualaniensis)、珠带拟蟹守螺和短拟沼螺等。海南岛西海岸红 树林软体动物优势种在不同地点有明显不同。马裒 湾和花场湾因为有河流的淡水输入, 使花蚬和斜肋 齿蜷这类能适应较低盐度的淡水型软体动物成为 第一优势种。樱蛤科的圆胖樱蛤在新盈湾的光滩占 绝对优势, 与张光星等(2016)对新盈彩桥红树林的 调查一致。新盈湾红树林内人类的贝类采捕活动频 繁, 青蛤(Cyclina sinensis)、文蛤(Meretrix meretrix) 和菲律宾蛤仔(Ruditapes philippinarum)等经济贝类 是渔民主要的采捕对象, 而圆胖樱蛤经济价值不高,
少有采捕。另一方面，圆胖樱蛤生长周期短、个体 小、繁殖快, 长而灵巧的入水管能在沉积物的表面 摄取并吸入有机碎屑，适应有机碎屑沉积较多的红 树林湿地，能迅速占据因人类采捕造成的生态位空 缺, 成为第一优势种。

\section{2 海南岛西海岸红树林软体动物群落结构特征}

海南岛西海岸红树林软体动物的密度和生物 量在旱、雨季间的差异均不显著，聚类分析的结果 也表明相同地点不同季节的软体动物群落种类组 成变化不大。陈光程等(2013)认为, 软体动物群落分 布存在的季节变化主要与环境因子的季节差异以 及软体动物自身的生活史有关。软体动物中很多种 类在发育完成时, 活动能力较弱, 只能栖息在固定 场所或活动范围有限(刘录三和李新正, 2003)。另 方面, 软体动物主要的繁殖期在温暖的春季(张笚 和齐钟彦，1961)。杨廷宝和沈寿彭(1992)研究发现， 深圳红树林珠带拟蟹守螺的繁殖高峰在5-9月，9月 之后到 12 月间死亡率很低, 种群数量变化不大。本 
次调查在 8 月和次年1月进行, 错开了软体动物主要 的繁殖期, 这可能是本研究旱、雨季间软体动物群 落种类组成变化不大的原因。而不同地点环境因子 的不同使海南岛西海岸不同红树林软体动物群落 结构存在明显差异。

红树林软体动物的群落结构受到海水盐度的 直接影响(Ashton et al, 2003)。张雅芝等(1999)研究 发现福建省红树林大型底栖动物的多样性与盐度 呈正相关关系。因为不同软体动物对盐度的适应范 围不同, 狭盐性软体动物无法分布到盐度波动较大 的水域, 而海洋软体动物以狭盐性变渗压种类为主, 因此盐度的降低和变动, 通常会伴随着软体动物种 类数目的减少(蔡英亚等, 1995)。马褒湾和花场湾淡 水流入带来的低盐度使软体动物种类数和多样性 较低, 主要的优势种为能够适应较低盐度的淡水型 软体动物, 群落结构与高盐度红树林差异明显。

底质粒径也是影响红树林软体动物群落结构 的重要环境因子(韩淑梅等, 2010)。盐丁红树林的红 树植物以红海榄(Rhizophora stylosa)为主, 底质粒 径较小, 主要为粉砂质粘壤土, 软体动物种数少且 密度和生物量最低, M-AMBI结果也显示, 盐丁的 软体动物生态环境质量显著低于其他地点。唐以杰 等(2015)认为, 红树林底质粒径小会限制土壤的透 气性, 严重制约红树林内软体动物的生存, 降低物 种多样性。海南岛西海岸不同红树林底质粒径的差 异性，造成了软体动物群落结构的差异性。

\section{3 海南岛西海岸红树林软体动物的价值与保护}

软体动物作为大型底栖动物的主要类群, 是鹳
类、鸥敄类和鸭类等水鸟主要的食物来源之一(林清 贤, 2003)。海南岛西海岸红树林承载着很高的软体 动物多样性, 其种类、密度和生物量远高于北部湾 大陆沿岸红树林(表5)。一方面，海南岛西海岸红树 林湿地是勺嘴楺和黑脸琵鹭等濒危候鸟重要的补 给站和越冬地。根据海南观鸟会的记录，自2011年 以来，在东方和新盈等地红树林多次发现勺嘴䂆的 身影; 2017年黑脸琵鹭全球同步普查报告中，海南 岛是黑脸琵鹭最南端的主要越冬地，全岛记录到的 67只黑脸琵鹭全部分布在西海岸, 并且有65只是在 红树林湿地被发现(Yu et al, 2018)。另一方面，迁徙 鸟类在北部湾其他的越冬地正逐渐丧失。广西沿海 红树林湿地也是黑脸琵鹭的越冬地之一, 在1995年 到2002年间每年可以记录到十只左右的黑脸琵鹭。 但近几年因为人类滨海活动的增加，黑脸琵鹭在广 西的记录明显减少, 2013年至今总共仅记录到3只 (孙仁杰, 2017; Yu et al, 2018)。因此，海南岛西海岸 作为北部湾的重要组成部分, 对迁徙鸟类的重要性 愈发突出。

M-AMBI指数表明西海岸红树林软体动物群落 目前所受扰动等级较低, 生态环境质量介于一般和 优良之间。虽然大规模直接破坏红树林的事件已经 很少发生，但一些威胁如：鱼塘排污(儋州湾、新盈 湾、马息湾、花场湾)、海鸭养殖(儋州湾、新盈湾)、 过度捕捞(新盈湾)、垃圾污染(儋州湾)和鱼藤危害 (马哀湾)等值得关注。2015年, 我们在儋州湾光滩发 现了入侵物种互花米草(Spartina alterniflora)。互花 米草已经对福建、广东、广西等地的红树林造成严

表5 北部湾不同红树林软体动物种类、密度和生物量的比较

Table 5 Comparison of mangrove mollusk diversity, density and biomass in Beibu Gulf

\begin{tabular}{lllll}
\hline 调查地点 Research sites & $\begin{array}{l}\text { 种数 } \\
\text { Species number }\end{array}$ & $\begin{array}{l}\text { 密度 } \\
\left.\text { Density (ind./ } \mathrm{m}^{2}\right)\end{array}$ & $\begin{array}{l}\text { 生物量 } \\
\text { Biomass }\left(\mathrm{g} / \mathrm{m}^{2}\right)\end{array}$ & $\begin{array}{l}\text { 数据来源 } \\
\text { Source of data }\end{array}$ \\
\hline 广西沿海 Guangxi Coast & 117 & - & - & Lai \& He, 1998 \\
广西北仑河口 Beilun Estuary, Guangxi & 49 & - & - & He et al, 2012 \\
广西防城港 Fangcheng Harbor, Guangxi & 125 & 234 & 126 & Liu, 2013 \\
广西茅尾海 Maowei Sea, Guangxi & 27 & - & - & Zhuang et al, 2009 \\
广西山口 Shankou, Guangxi & 81 & - & 46 & Fan et al, 2005 \\
广东廉江高桥 Gaoqiao, Lianjiang, Guangdong & 158 & 115 & - & Liu, 2013 \\
广东雷州半岛 Leizhou Peninsula, Guangdong & 110 & - & 192 & Han et al, 2004 \\
海南东寨港 Dongzhai Harbor, Hainan & 149 & 373 & 149 & 章慧, 2016 \\
海南岛西海岸 West coast of Hainan & 201 & 312 & 本文 This study \\
\hline
\end{tabular}

- 缺乏数据 Lack of data

(1)章慧 (2016) 海南东寨港红树林生境异质性对软体动物多样性的影响. 硕士学位论文, 厦门大学, 厦门. 
重威胁(左平等, 2009)。此外, 四必湾和新盈湾引种 的拉关木(Laguncularia racemosa) 存在快速扩散的 现象, 需要引起关注。海南岛西海岸较低的红树植 物种类多样性支撑着较高的软体动物多样性, 对于 红树林修复时引进外来种造林的必要性有待商榷。

\section{参考文献}

Ashton EC, Macintosh DJ, Hogarth PJ (2003) A baseline study of the diversity and community ecology of crab and molluscan macrofauna in the Sematan mangrove forest, Sarawak, Malaysia. Journal of Tropical Ecology, 19, 127-142.

Barbier EB, Hacker SD, Kennedy C, Koch EW, Stier AC, Silliman BR (2011) The value of estuarine and coastal ecosystem services. Ecological Monographs, 81, 169-193.

Cai LZ, Chen XQ, Wu C, Peng X, Cao J, Fu SJ (2011) Temporal and spatial variation of macrofaunal communities in Shenzhen Bay intertidal zone between 1995 and 2010. Biodiversity Science, 19, 702-709. (in Chinese with English abstract) [蔡立哲, 陈昕群, 吴辰, 彭欣, 曹婧, 傅素晶 (2011) 深圳湾潮间带1995-2010年大型底栖动物群落的 时空变化. 生物多样性, 19, 702-709.]

Cai LZ (2015) Zoobenthic Ecology in Shenzhen Bay. Xiamen University Press, Xiamen. (in Chinese) [蔡立哲 (2015) 深 圳湾底栖动物生态学. 厦门大学出版社, 厦门.]

Cai YY, Zhang Y, Wei RF (1995) Introduction to Malacology. Shanghai Scientific and Technical Publishers, Shanghai. (in Chinese) [蔡英亚, 张英, 魏若飞 (1995) 贝类学概论. 上 海科学技术出版社, 上海.]

Chen GC, Yu D, Ye Y, Chen B (2013) Impacts of mangrove vegetation on macro-benthic faunal communities. Acta Ecologica Sinica, 33, 327-336. (in Chinese with English abstract) [陈光程, 余丹, 叶勇, 陈涁 (2013) 红树林植被对 大型底栖动物群落的影响. 生态学报, 33, 327-336.]

Dan XQ, Liao BW, Wu ZB, Wu HJ, Bao DM, Dan WY, Liu SH (2016) Resources, conservation status and main threats of mangrove wetlands in China. Ecology and Environmental Sciences, 25, 1237-1243. (in Chinese with English abstract) [但新球, 廖宝文, 吴照柏, 吴后建, 鲍达明, 但维宇, 刘 世好 (2016) 中国红树林湿地资源、保护现状和主要威 胁. 生态环境学报, 25, 1237-1243.]

Fan HQ, Chen GH, He BY (2005) Coastal Wetland and Management of Shankou Mangroves. China Ocean Press, Beijing. (in Chinese) [范航清, 陈光华, 何斌源 (2005) 山口 红树林滨海湿地与管理. 海洋出版社, 北京.]

Han SM, He P, Huang B, Zhong CR, Wang XJ, Guo H (2010) Comparative study on the diversity of macrobenthos in typical mangrove regions of Dongzhai Harbor, Hainan Island. Journal of Northwest Forestry University, 25(1), 123-126. (in Chinese with English abstract) [韩淑梅, 何平, 黄勃, 钟才荣, 王先静, 郭恒 (2010) 东寨港典型红树林区底栖 动物多样性特征指数比较研究. 西北林学院学报, 25(1),
123-126.]

Han WD, Cai YY, Liu JK, Lao Z, Li ZM, Luo YM (2003) Molluscs of mangrove areas in Leizhou Peninsula, China. Journal of Zhanjiang Ocean University, 23(1), 1-7. (in Chinese with English abstract) [韩维栋, 蔡英亚, 刘劲科, 劳 赞, 栗志民, 罗远谋 (2003) 雷州半岛红树林海区的软体 动物. 湛江海洋大学学报, 23(1), 1-7.]

Han WD, Liu JK, Cai YY, Wu XD, Teunisson E, Cai JX (2004) Biodiversity and biomass of molluscs in mangrove areas of Leizhou Peninsula. Forestry Science and Technology, 29(1), 17-21. (in Chinese with English abstract) [韩维 栋, 刘劲科, 蔡英亚, 吴晓东, Edwin Teunisson, 蔡俊欣 (2004) 雷州半岛红树林区软体动物多样性与生物量研 究. 林业科技, 29(1), 17-21.]

He XY, Su B, Xu TB, Nong LC, Ye CF, Li XY (2012) Macrobenthic biodiversity in mangrove wetland at the estuary of Beilun River in Guangxi. Wetland Science and Management, 8(2), 44-48. (in Chinese with English abstract) [何祥 英, 苏搏, 许廷波, 农立成, 叶朝放, 李啸宇 (2012) 广 西北仑河口红树林湿地大型底栖动物多样性的初步研究. 湿地科学与管理, 8(2), 44-48.]

Kristensen E, Bouillon S, Dittmar T, Marchand C (2008) Organic carbon dynamics in mangrove ecosystems: A review. Aquatic Botany, 89, 201-219.

Lai TH, He BY (1998) Studies on the macrobenthos species diversity for Guangxi mangrove areas. Guangxi Sciences, 5, 166-172. (in Chinese with English abstract) [赖廷和, 何斌 源 (1998) 广西红树林区大型底栖动物种类多样性研究. 广西科学, 5, 166-172.]

Lin P (1997) Mangrove Ecosystem in China. Science Press, Beijing. (in Chinese) [林鹏 (1997) 中国红树林生态系. 科 学出版社, 北京.]

Lin QX (2003) Bird in Southern Fujian Mangrove Areas and Its Correlationship with Macrobenthic. PhD dissertation, Xiamen University, Xiamen. (in Chinese with English abstract) [林清贤 (2003) 闽南沿海红树林区乌类及其与大 型底栖动物相关关系研究. 博士学位论文, 厦门大学, 厦 门.]

Liu LS, Li XZ (2003) Distribution of macrobenthos in spring and autumn in the southern Yellow Sea. Oceanologia et Limnologia Sinica, 34, 26-32. (in Chinese with English abstract) [刘录三, 李新正 (2003) 南黄海春秋季大型底栖 动物分布现状. 海洋与湖沼, 34, 26-32.]

Liu Y (2013) Ecological Studies on Mangrove Molluscs based on Typical Mangrove Communities. PhD dissertation, Xiamen University, Xiamen. (in Chinese with English abstract) [刘毅 (2013) 基于典型红树植物群落的红树林软体动物 生态研究. 博士学位论文, 厦门大学, 厦门.]

Margalef R (1968) Perspectives in Ecological Theory. University of Chicago Press, Chicago.

Pielou EC (1975) Ecology Diversity. John Wiley and Sons, New York.

Pinto R, Patrício J, Baeta A, Fath BD, Neto JM, Marques JC 
(2009) Review and evaluation of estuarine biotic indices to assess benthic condition. Ecological Indicators, 9, 1-25.

Shannon CE, Weaver W (1949) The Mathematical Theory of Communication. University of Illinois Press, Urbanna.

Sun RJ (2017) “Black-faced dancer”: Black-faced spoonbills. Forestry of Guangxi, (3), 18-19. (in Chinese) [孙仁杰 (2017) “黑面舞者”黑脸琵鹭. 广西林业, (3), 18-19.]

Tang YJ, Yu SX (2007) Spatial zonation of macrofauna in the Zhanjiang Mangrove Nature Reserve, Guangdong. Acta Ecologica Sinica, 27, 1703-1714. (in Chinese with English abstract) [唐以杰, 余世孝 (2007) 广东湛江红树林保护 区大型底栖动物群落的空间分带. 生态学报, 27, 1703-1714.]

Tang YJ, Chen K, Liu JL (2015) The structure of the mollusca community and niche analysis in Zhanjiang Mangrove Nature Reserves. Journal of Guangdong University of Education, 35(3), 65-70. (in Chinese with English abstract) [唐以 杰, 陈康, 刘金苓 (2015) 湛江红树林保护区软体动物群 落结构与生态位分析. 广东第二师范学院学报, 35(3), 65-70.]

Wang M, Liu Y, Ding YP, Zhong CR, Li HL, Wang WQ (2013) Mangrove Molluscs of Dongzhaigang, Hainan. Xiamen University Press, Xiamen. (in Chinese) [王瑁, 刘毅, 丁弯朋, 钟才荣, 李华亮, 王文卿 (2013) 海南东寨港红 树林软体动物. 厦门大学出版社, 厦门.]

Wang WQ, Wang M (2007) The Mangroves of China. Science Press, Beijing. (in Chinese) [王文卿, 王瑁 (2007) 中国红 树林. 科学出版社, 北京.]

Xu ZL, Chen YQ (1989) Aggregated intensity of dominant species of zooplankton in autumn in the East China Sea and Yellow Sea. Journal of Ecology, 8(4), 13-15. (in Chinese with English abstract) [徐兆礼, 陈亚篗 (1989) 东黄海秋 季浮游动物优势种聚集强度与鲐鲹渔场的关系. 生态学 杂志, 8(4), 13-15.]

Yang TB, Shen SP (1992) Studies of the population ecology of Cerithidea cingulata (Gmelin) in the mangrove area of $\mathrm{Fu}-$ tian, Shenzhen. Supplement to the Journal of Sun Yatsen University, (3), 85-92. (in Chinese with English abstract)
[杨廷宝, 沈寿彭 (1992) 深圳红树林区珠带拟蟹守螺的 种群生态研究. 中山大学学报论丛, (3), 85-92.]

Yu YT, Tse IWL, Fong HHN (2018) International Black-faced Spoonbill Census 2017. Blackfaced Spoonbill Research Group, The Hong Kong Bird Watching Society, Hong Kong.

Zhang GX, Lan JX, Wu R, Wang DR (2016) Preliminary study on macrozoobenthos diversity in mangrove area of Hainan Province. Chinese Journal of Tropical Agriculture, 36(11), 37-42. (in Chinese with English abstract) [张光星, 兰建新, 吴瑞, 王道儒 (2016) 海南省红树林区大型底栖动物多 样性的初步研究. 热带农业科学, 36(11), 37-42.]

Zhang X, Qi ZY (1961) Essentials of Malacology. Science Press, Beijing. (in Chinese) [张胥, 齐钟彦 (1961) 贝类学 纲要. 科学出版社, 北京.]

Zhang YZ, Chen CZ, Wang YY, Chen PJ, Yang RQ (1999) The ecology of benthos in Fujian mangrove swamps. Acta Ecologica Sinica, 19, 896-901. (in Chinese with English abstract) [张雅芝, 陈灿忠, 王渊源, 陈品健, 杨瑞琼 (1999) 福建红树林区底栖生物生态研究. 生态学报, 19, 896-901.]

Zhuang JL, He BJ, Xu MB (2009) Ecological features of the intertidal benthos in the Qinzhou Maowei Gulf of Guangxi. Guangxi Sciences, 16, 96-100. (in Chinese with English abstract) [庄军莲, 何碧娟, 许铭本 (2009) 广西钦州茅尾海 潮间带生物生态特征. 广西科学, 16, 96-100.]

Zou FS, Zhang HH, Dahmer T, Yang QF, Cai JX, Zhang W, Liang CY (2008) The effects of benthos and wetland area on shorebird abundance and species richness in coastal mangrove wetlands of Leizhou Peninsula, China. Forest Ecology and Management, 255, 3813-3818.

Zuo P, Liu CA, Zhao SH, Wang CH, Liang YB (2009) Distribution of Spartina plantations along the China's coast. Acta Oceanologica Sinica, 31(5), 101-111. (in Chinese with English abstract) [左平, 刘长安, 赵书河, 王春红, 梁玉波 (2009) 米草属植物在中国海岸带的分布现状. 海洋学报, 31(5), 101-111.]

(责任编委: 李新正 责任编辑: 闵文杰)

\section{附录 Supplementary Material}

附录1 海南岛西海岸红树林软体动物种类名录

Appendix 1 Species list of mangrove mollusk in the west coast of Hainan Island http://www.biodiversity-science.net/fileup/PDF/2018104-1.pdf 
马维, 王琩, 王文卿, 刘毅, 罗柳青, 唐朝艺. 海南岛西海岸红树林软体动物多样性. 生物多样性, 2018, 26 (7): 707-716.

http://www.biodiversity-science.net/CN/10.17520/biods.2018104

附录1 海南岛西海岸红树林软体动物种类名录

Appendix 1 Species list of mangrove mollusk in the west coast of Hainan Island

\begin{tabular}{|c|c|c|c|c|c|c|c|c|c|}
\hline & & $\begin{array}{l}\text { 中文名 } \\
\text { Chinese name }\end{array}$ & $\begin{array}{l}\text { 学名 } \\
\text { Scientific name }\end{array}$ & $\begin{array}{l}\text { 四必湾 } \\
\text { Sibi Bay }\end{array}$ & $\begin{array}{c}\text { 儋州湾 } \\
\text { Danzhou Bay }\end{array}$ & $\begin{array}{l}\text { 盐丁 } \\
\text { Yanding }\end{array}$ & $\begin{array}{c}\text { 新盈湾 } \\
\text { Xinving Bay }\end{array}$ & $\begin{array}{c}\text { 马裹湾 } \\
\text { Maniao Bay }\end{array}$ & $\begin{array}{c}\text { 花场湾 } \\
\text { Huachang Bay }\end{array}$ \\
\hline 双壳纲 & Bivalvia & & & & & & & & \\
\hline 蚶目 & Arcoida & & & & & & & & \\
\hline \multirow[t]{10}{*}{ 蚶科 } & Arcidae & 古蚶 & Anadara antiquata & & & + & & & + \\
\hline & & 联球蚶 & Anadara consociata & & + & & + & & \\
\hline & & 找线粗饰蚶 & Anadara uropigimelana & & & & + & & + \\
\hline & & 青蚶 & Barbatia obliquata & + & & & + & & \\
\hline & & 角毛蚶 & Scapharca cornea & + & + & & + & & \\
\hline & & 毛蚹 & Scapharca kagoshimensis & + & + & & + & & \\
\hline & & 赛氏毛蚶 & Scapharca satowi & & & & + & & \\
\hline & & 托氏毛蚶 & Scapharca troscheli & & & & + & & \\
\hline & & 泥蚶 & Tegillarca granosa & + & + & & & & + \\
\hline & & 结蚶 & Tegillarca nodifera & + & + & & & & \\
\hline 贻贝目 & Mytiloida & & & & & & & & \\
\hline \multirow[t]{5}{*}{ 贻贝科 } & Mytilidae & 变化短齿蛤 & Brachidontes variabilis & & + & + & + & + & \\
\hline & & 曲线索贻贝 & Hormomya mutabilis & & & & + & & \\
\hline & & 寻氏肌蛤 & Musculus senhousia & + & & & & & + \\
\hline & & 翡翠贻贝 & Perna viridis & + & + & + & + & + & + \\
\hline & & 黑养麦蛤 & Xenostrobus atratus & & & & & & + \\
\hline 江珧科 & Pinnidae & 栉江珧 & Atrina pectinata & + & & & & & \\
\hline 珍珠贝目 & Pterioida & & & & & & & & \\
\hline 珍珠贝科 & Pteriidae & 长耳珠母贝 & Pinctada chemnitzi & + & + & & & & \\
\hline 钳蛤科 & Isognomonidae & 扁平钳蛤 & Isognomon ephippium & & & + & + & & + \\
\hline
\end{tabular}


马维, 王琩, 王文卿, 刘毅, 罗柳青, 唐朝艺. 海南岛西海岸红树林软体动物多样性. 生物多样性, 2018, 26 (7): 707-716. http://www.biodiversity-science.net/CN/10.17520/biods.2018104

\begin{tabular}{|c|c|c|c|c|c|c|c|c|c|}
\hline & & 中文名 & 学名 & 四必湾 & 儋州湾 & 盐丁 & 新盈湾 & 马裒湾 & 花场湾 \\
\hline & & Chinese name & Scientific name & Sibi Bay & & & & & \\
\hline & & 豆荚钳蛤 & Isognomon legumen & + & & & & & \\
\hline 扇贝科 & Pectinidae & 华贵类栉孔扇贝 & Mimachlamys nobilis & & & & + & & \\
\hline \multirow[t]{2}{*}{ 不等蛤科 } & Anomiidae & 中国不等蛤 & Anomia chinensis & + & & & & & \\
\hline & & 难解不等蛤 & Enigmonia aenigmatica & + & + & & + & + & + \\
\hline \multirow[t]{2}{*}{ 海月科 } & Placunidae & 鞍海月 & Placuna ephippium & & & & + & & \\
\hline & & 海月 & Placuna placenta & + & & + & + & & + \\
\hline 牡蚛目 & Osteroida & & & & & & & & \\
\hline \multirow[t]{2}{*}{ 缘曲牡蚛科 } & Gryphaeidae & 舌骨告蚛 & Hyotissa hyotis & & & & + & & \\
\hline & & 覆瓦告蚛 & Parahyotissa imbricata & + & + & + & & & \\
\hline \multirow[t]{6}{*}{ 牡蚛科 } & Ostreidae & 近江牡蚛 & Crassostrea ariakensis & & + & & & & \\
\hline & & 鹅掌牡蚛 & Planostrea pestigris & + & & & & & \\
\hline & & 僧帽生蚛 & Saccostrea cucullata & & & + & & & \\
\hline & & 棘刺牡蚛 & Saccostrea echinata & & & + & + & & \\
\hline & & 团聚牡蚛 & Saccostrea glomerata & + & + & + & + & + & + \\
\hline & & 咬齿生蚛 & Saccostrea mordax & & & + & & & \\
\hline 穿蛤目 & Veneroida & & & & & & & & \\
\hline \multirow[t]{4}{*}{ 满月蛤科 } & Lucinidae & 无齿蛤 & Anodontia edentula & + & & & & & \\
\hline & & 强肋厚大蛤 & Codakia golikovi & + & & & & & \\
\hline & & 印澳蛤 & Indoaustriella plicifera & & + & & + & & + \\
\hline & & 斯氏印澳蛤 & Indoaustriella scarlatoi & & + & & + & + & + \\
\hline \multirow[t]{3}{*}{ 鸟蛤科 } & Cardiidae & 黄边粘鸟蛤 & Trachycardium flavum & + & & & + & & \\
\hline & & 暗斑糙鸟蛤 & Trachycardium nigropunctatum & & & & + & & \\
\hline & & 单色踈鸟蛤 & Trachycardium unicolor & + & & & & & \\
\hline 蛤蜊科 & Mactridae & 西施舌 & Coelomactra antiquata & + & & & & & \\
\hline
\end{tabular}


马维, 王琩, 王文卿, 刘毅, 罗柳青, 唐朝艺. 海南岛西海岸红树林软体动物多样性. 生物多样性, 2018, 26 (7): 707-716. http://www.biodiversity-science.net/CN/10.17520/biods.2018104

\begin{tabular}{|c|c|c|c|c|c|c|c|c|c|}
\hline & & 中文名 & 学名 & 四必湾 & 儋州湾 & 盐丁 & 新盈湾 & 马噮湾 & 花场湾 \\
\hline & & Chinese name & Scientific name & Sibi Bay & & & & & Huachang Bay \\
\hline & & 克氏腔蛤蜊 & Coelomactra cumingi & + & & & & & \\
\hline & & 四角蛤蜊 & Mactra veneriformis & + & & + & & & \\
\hline & & 透明立蛤 & Meropesta pellicula & & & & + & & \\
\hline \multirow[t]{2}{*}{ 中带蛤科 } & Mesodesmatidae & 台湾朽叶蛤 & Coecella formaosae & & + & + & & & + \\
\hline & & 朽叶蛤 & Coecella horsfieldi & + & & & & & \\
\hline \multirow[t]{8}{*}{ 樱蛤科 } & Tellinidae & 灯白樱蛤 & Macoma lucerna & + & + & & & & \\
\hline & & 华贵白樱蛤 & Macoma nobilis & & + & & & + & \\
\hline & & 拟箱美丽蛤 & Merisca capsoides & + & + & + & + & & \\
\hline & & 凸壳明樱蛤 & Moerella corbuloides & & & & & + & \\
\hline & & 刀明樱蛤 & Moerella culter & + & + & + & & & \\
\hline & & 亮樱蛤 & Nitidotellina dunkeri & & & & + & & \\
\hline & & 幼形亮樱蛤 & Nitidotellina juvenilis & & + & & & & \\
\hline & & 圆胖樱蛤 & Pinguitellina cycladiformis & & & + & + & + & \\
\hline 双带蛤科 & Semelidae & 齿纹双带蛤 & Semele crenulata & & & & + & & \\
\hline \multirow[t]{2}{*}{ 斧蛤科 } & Donacidae & 楔形斧蛤 & Donax cuneatus & + & & & & & \\
\hline & & 豆斧蛤 & Donax faba & + & & & & & \\
\hline \multirow[t]{7}{*}{ 紫云蛤科 } & Psammobiidae & 对生塑蛤 & Asaphis violascens & & & & + & & \\
\hline & & 尖紫蛤 & Sanguinolaria acuta & & + & & & & \\
\hline & & 疑紫蛤 & Sanguinolaria ambigua & + & & & & & \\
\hline & & 中国紫蛤 & Sanguinolaria chinensis & + & + & & + & & \\
\hline & & 长紫蛤 & Sanguinolaria elongata & + & + & & + & & \\
\hline & & 胖紫蛤 & Sanguinolaria inflata & & + & & & & \\
\hline & & 绿紫蛤 & Sanguinolaria virescens & & & & & + & \\
\hline 截蛏科 & Solecurtidae & 斯氏仿缢蛏 & Azorinus scheepmakeri & & + & & + & & + \\
\hline
\end{tabular}


马维, 王琩, 王文卿, 刘毅, 罗柳青, 唐朝艺. 海南岛西海岸红树林软体动物多样性. 生物多样性, 2018, 26 (7): 707-716. http://www.biodiversity-science.net/CN/10.17520/biods.2018104

\begin{tabular}{|c|c|c|c|c|c|c|c|c|c|}
\hline & & 中文名 & 学名 & 四必湾 & 儋州湾 & 盐丁 & 新盈湾 & 马裒湾 & 花场湾 \\
\hline & & Chinese name & Scientific name & & & & Xinying Bay & & \\
\hline & & 总角截蛏 & Solecurtus divaricatus & & & & + & & \\
\hline 竹蛏科 & Solenidae & 长竹蛏 & Solen strictus & + & & & & & \\
\hline 刀蛏科 & Cultellidae & 尖齿灯塔蛏 & Pharella acutidens & & + & & + & + & + \\
\hline 饰贝科 & Dreissenidae & 萨氏仿贻贝 & Mytilopsis sallei & & & & + & + & \\
\hline \multirow[t]{2}{*}{ 稜蛤科 } & Trapeziidae & 斑纹棱蛤 & Trapezium liratum & & + & & + & + & + \\
\hline & & 亚光稜蛤 & Trapezium sublaevigatum & & + & & & & \\
\hline \multirow[t]{4}{*}{ 蚬科 } & Corbiculidae & 河蚬 & Corbicula fluminea & + & + & + & & + & \\
\hline & & 凹线仙女蚬 & Cyrenobatissa subsulcata & & & + & + & & \\
\hline & & 花蚬 & Cyrenodonax formosana & & + & + & + & & \\
\hline & & 红树蚬 & Geloina coaxans & & + & & + & + & + \\
\hline \multirow[t]{14}{*}{ 帘蛤科 } & Veneridae & 鳞杓拿蛤 & Anomalodiscus squamosus & + & + & + & + & & + \\
\hline & & 面具美女蛤 & Circe personata & + & & & + & & \\
\hline & & 美女蛤 & Circe scripta & + & + & & + & & + \\
\hline & & 华丽美女蛤 & Circe tumefacta & + & + & & & & \\
\hline & & 伊萨伯雪蛤 & Clausinella isabellina & + & + & & + & & + \\
\hline & & 头巾雪蛤 & Clausinella tiara & + & & & & & \\
\hline & & 突畸心蛤 & Cryptonema producta & + & + & & + & & \\
\hline & & 青蛤 & Cyclina sinensis & + & + & + & + & & \\
\hline & & 巧环楔形蛤 & Cyclosunetta concinna & + & & & & & \\
\hline & & 高镜蛤 & Dosinia altior & & + & & & & \\
\hline & & 刺镜蛤 & Dosinia aspera & & + & & & & \\
\hline & & 铗镜蛤 & Dosinia fibula & + & & & & & \\
\hline & & 日本镜蛤 & Dosinia japonica & + & + & & & & \\
\hline & & 加夫蛤 & Gafrarium pectinatum & + & + & + & + & & + \\
\hline
\end{tabular}


马维, 王琩, 王文卿, 刘毅, 罗柳青, 唐朝艺. 海南岛西海岸红树林软体动物多样性. 生物多样性, 2018, 26 (7): 707-716. http://www.biodiversity-science.net/CN/10.17520/biods.2018104

\begin{tabular}{|c|c|c|c|c|c|c|c|c|c|}
\hline & & $\begin{array}{l}\text { 中文名 } \\
\text { Chinese name }\end{array}$ & $\begin{array}{l}\text { 学名 } \\
\text { Scientific name }\end{array}$ & $\begin{array}{l}\text { 四必湾 } \\
\text { Sibi Bav }\end{array}$ & $\begin{array}{c}\text { 儋州湾 } \\
\text { Danzhou Bav }\end{array}$ & $\begin{array}{l}\text { 盐丁 } \\
\text { Yanding }\end{array}$ & $\begin{array}{c}\text { 新盈湾 } \\
\text { Xinving Bav }\end{array}$ & $\begin{array}{c}\text { 马晨湾 } \\
\text { Maniao Bav }\end{array}$ & $\begin{array}{c}\text { 花场湾 } \\
\text { Huachang Bay }\end{array}$ \\
\hline & & 凸加夫蛤 & Gafrarium tumidum & + & & & + & & + \\
\hline & & 等边浅蛤 & Gomphina aequilatera & + & & & & & \\
\hline & & 雉纹光壳蛤 & Lioconcha fastigiana & + & & & & & \\
\hline & & 裂纹格特蛤 & Marcia hiantina & + & + & & + & & + \\
\hline & & 日本格特蛤 & Marcia japonica & + & & & + & & \\
\hline & & 丽文蛤 & Meretrix lusoria & + & + & & + & + & \\
\hline & & 琴文蛤 & Meretrix lyrata & + & + & & + & & \\
\hline & & 文蛤 & Meretrix meretrix & + & + & & + & + & \\
\hline & & 小文蛤 & Meretrix planisulcata & + & + & & & & \\
\hline & & 锯齿巴非蛤 & Paphia gallus & & & & + & & \\
\hline & & 波纹巴非蛤 & Paphia undulata & + & + & & & & \\
\hline & & 细纹卵蛤 & Pitar striatum & + & & & & & \\
\hline & & 柱状卵蛤 & Pitar sulfureum & & & & + & & \\
\hline & & 菲律宾蛤仔 & Ruditapes philippinarum & + & + & + & + & & \\
\hline & & 杂色蛤仔 & Ruditapes variegata & + & & & & & \\
\hline & & 短圆缀锦蛤 & Tapes deshayesii & + & & & & & \\
\hline \multirow[t]{3}{*}{ 绿螂科 } & Glauconomidae & 绿螂 & Glauconome chinensis & + & + & & + & + & + \\
\hline & & 皱纹绿螂 & Glauconome corrugata & + & + & & + & + & \\
\hline & & 薄壳绿螂 & Glauconome primeana & + & & & & & \\
\hline 海螂目 & Myoida & & & & & & & & \\
\hline \multirow[t]{2}{*}{ 蓝蛤科 } & Corbulidae & 射带河蓝蛤 & Potamocorbula fasciata & & + & & & & \\
\hline & & 光滑蓝蛤 & Potamocorbula laevis & & & & & + & \\
\hline 海笋科 & Pholadidae & 马特海笋 & Martesia striata & + & & & & & \\
\hline 船蛆科 & Teredinidae & 裂铠船蛆 & Teredo manni & + & + & & & & \\
\hline
\end{tabular}


马维, 王琩, 王文卿, 刘毅, 罗柳青, 唐朝艺. 海南岛西海岸红树林软体动物多样性. 生物多样性, 2018, 26 (7): 707-716. http://www.biodiversity-science.net/CN/10.17520/biods.2018104

\begin{tabular}{|c|c|c|c|c|c|c|c|c|c|}
\hline & & 中文名 & 学名 & 四必湾 & 儋州湾 & 盐丁 & 新盈湾 & 马蓑湾 & 花场湾 \\
\hline & & Chinese name & Scientific name & Sibi Bay & Danzhou Bay & Yanding & Xinying Bay & Maniao Bay & Huachang Bay \\
\hline 笋螂目 & Pholadomyoida & & & & & & & & \\
\hline \multirow[t]{3}{*}{ 鸭嘴蛤科 } & Laternulidae & 鸭嘴蛤 & Laternula anatina & & + & & + & + & + \\
\hline & & 剖刀鸭嘴蛤 & Laternula boschasina & & + & & & & \\
\hline & & 截形鸭嘴蛤 & Laternula truncata & & + & & & + & + \\
\hline 腹足纲 & Gastropoda & & & & & & & & \\
\hline 原始腹足目 & Archaeogastropoda & & & & & & & & \\
\hline 笠贝科 & Acmaeidae & 矮拟帽贝 & Patelloida pygmaea & & + & & & & \\
\hline \multirow[t]{4}{*}{ 马蹄螺科 } & Trochidae & 粗粘真蹄螺 & Euchelus scaber & + & + & & & & \\
\hline & & 塔形扭柱螺 & Tectus pyramis & & & + & & & \\
\hline & & 托氏䗉螺 & Umbonium thomasi & + & & & & & \\
\hline & & 䗉螺 & Umbonium vestiarium & + & & & & & \\
\hline 蝾螺科 & Turbinidae & 粒花冠小月螺 & Lunella coronata granulata & + & + & & & & \\
\hline \multirow[t]{9}{*}{ 蜒螺科 } & Neritidae & 豆彩螺 & Clithon faba & + & & + & + & + & + \\
\hline & & 奥莱彩螺 & Clithon oualaniensis & + & + & + & & + & + \\
\hline & & 渔舟蜒螺 & Nerita albicilla & + & & + & & & \\
\hline & & 变色蜒螺 & Nerita chamaeleon & & & + & & & \\
\hline & & 线纹蜒螺 & Nerita lineata & + & & & + & & \\
\hline & & 圆蜒螺 & Nerita squamulata & + & & + & & & \\
\hline & & 齿纹蜒螺 & Nerita yoldi & + & & + & & & \\
\hline & & 平行线游螺 & Neritina paralella & & & & & + & + \\
\hline & & 紫游螺 & Neritina violacea & + & & & + & + & + \\
\hline 中腹足目 & Mesogastropoda & & & & & & & & \\
\hline 瓶螺科 & Ampullariidae & 大瓶螺 & Pomacea canaliculata & + & + & + & & & + \\
\hline 滨螺科 & Littorinidae & 斑肋滨螺 & Littoraria ardouiniana & + & + & + & + & & + \\
\hline
\end{tabular}


马维, 王琩, 王文卿, 刘毅, 罗柳青, 唐朝艺. 海南岛西海岸红树林软体动物多样性. 生物多样性, 2018, 26 (7): 707-716. http://www.biodiversity-science.net/CN/10.17520/biods.2018104

\begin{tabular}{|c|c|c|c|c|c|c|c|c|c|}
\hline & & 中文名 & 学名 & 四必湾 & 儋州湾 & 盐丁 & 新盈湾 & 马臭湾 & 花场湾 \\
\hline & & Chinese name & Scientific name & Sibi Bay & Danzhou Bay & Yanding & Xinying Bay & Maniao Bay & Huachang Bay \\
\hline & & 中间拟滨螺 & Littoraria intermedia & + & + & & & & \\
\hline & & 黑口滨螺 & Littoraria melanostoma & + & + & + & + & + & + \\
\hline & & 浅黄滨螺 & Littoraria pallescens & + & + & + & & & + \\
\hline & & 粗精滨螺 & Littoraria scabra & + & + & + & + & + & + \\
\hline & & 波纹滨螺 & Littoraria undulata & + & + & + & & & \\
\hline & & 蛋挞滨螺 & Mainwaringia dantaae & & & & & + & + \\
\hline \multirow[t]{2}{*}{ 黑螺科 } & Melanidae & 瘤拟黑螺 & Melanoides tuberculata & & & + & & + & + \\
\hline & & 斜肋齿蜷 & Sermyla riquetii & + & + & & + & + & + \\
\hline \multirow[t]{3}{*}{ 拟沼螺科 } & Assimineidae & 短拟沼螺 & Assiminea brevicula & + & + & + & + & + & + \\
\hline & & 绯拟沼螺 & Assiminea latericea & + & + & + & + & + & + \\
\hline & & 林氏拟沼螺 & Taiwanassiminea hayasii & & & & & + & + \\
\hline \multirow[t]{2}{*}{ 雉螺科 } & Turritellidae & 棒雉螺 & Turritella bacillum & + & & + & & & \\
\hline & & 雉螺 & Turritella terebra & + & & & & & \\
\hline 蛇螺科 & Vermetidae & 覆瓦小蛇螺 & Serpulorbis imbricatus & + & & & + & + & \\
\hline \multirow[t]{4}{*}{ 滩栖螺科 } & Batillariidae & 疮滩栖螺 & Batillaria broni & + & & & & & \\
\hline & & 古氏滩栖螺 & Batillaria cumingii & + & + & + & + & & \\
\hline & & 多形滩栖螺 & Batillaria multiformis & + & + & + & + & + & + \\
\hline & & 纵带滩栖螺 & Batillaria zonalis & + & + & + & + & & \\
\hline \multirow[t]{3}{*}{ 蟹守螺科 } & Cerithiidae & 特氏蟹守螺 & Cerithium traillii & + & & & + & & \\
\hline & & 石楯桑葚螺 & Clypeomorus coralia & & & + & & & \\
\hline & & 双带楯桑葚螺 & Clypeomorus humilis & + & + & + & & & \\
\hline \multirow[t]{3}{*}{ 汇螺科 } & Potamididae & 珠带拟蟹守螺 & Cerithidea cingulata & + & + & + & + & + & + \\
\hline & & 查加拟蟹守螺 & Cerithidea djadjariensis & + & + & & & & \\
\hline & & 尖雉拟蟹守螺 & Cerithidea largillierti & + & + & + & & & \\
\hline
\end{tabular}


马维, 王琩, 王文卿, 刘毅, 罗柳青, 唐朝艺. 海南岛西海岸红树林软体动物多样性. 生物多样性, 2018, 26 (7): 707-716. http://www.biodiversity-science.net/CN/10.17520/biods.2018104

\begin{tabular}{|c|c|c|c|c|c|c|c|c|c|}
\hline & & $\begin{array}{l}\text { 中文名 } \\
\text { Chinese name }\end{array}$ & $\begin{array}{l}\text { 学名 } \\
\text { Scientific name }\end{array}$ & $\begin{array}{l}\text { 四必湾 } \\
\text { Sibi Bay }\end{array}$ & $\begin{array}{c}\text { 儋州湾 } \\
\text { Danzhou Bay }\end{array}$ & $\begin{array}{c}\text { 盐丁 } \\
\text { Yanding } \\
\end{array}$ & $\begin{array}{c}\text { 新盈湾 } \\
\text { Xinying Bay }\end{array}$ & $\begin{array}{c}\text { 马䁵湾 } \\
\text { Maniao Bay }\end{array}$ & $\begin{array}{c}\text { 花场湾 } \\
\text { Huachang Bay }\end{array}$ \\
\hline & & 小翼拟蟹守螺 & Cerithidea microptera & + & + & + & + & & \\
\hline & & 彩拟蟹守螺 & Cerithidea ornata & + & + & + & + & + & + \\
\hline & & 红树拟蟹守螺 & Cerithidea rhizophorarum & + & + & + & + & & \\
\hline & & 泥笋光螺 & Terebralia palustris & & & + & & + & \\
\hline & & 沟纹笋光螺 & Terebralia sulcata & + & & + & + & + & + \\
\hline \multirow[t]{4}{*}{ 玉螺科 } & Naticidae & 乳玉螺 & Mammilla mammata & & & & + & & \\
\hline & & 格纹玉螺 & Natica gualtieriana & + & + & & & & \\
\hline & & 齐氏玉螺 & Natica qizhongyani & + & & & + & & \\
\hline & & 斑玉螺 & Natica tigrina & + & + & & & & \\
\hline \multirow[t]{2}{*}{ 狭口螺科 } & Stenothyridae & 田边狭口螺 & $\begin{array}{l}\text { Stenothyra edogawensis } \\
\text { tanabensis }\end{array}$ & & & & & + & + \\
\hline & & 光滑狭口螺 & Stenothyra glabra & & & + & + & + & + \\
\hline \multirow[t]{2}{*}{ 河口螺科 } & Iravadiidae & 河口螺未定种 1 & Ceratia sp.1 & + & & & & + & + \\
\hline & & 河口螺未定种 2 & Ceratia sp.2 & & & & & + & \\
\hline 新腹足目 & Neogastropoda & & & & & & & & \\
\hline \multirow[t]{4}{*}{ 骨螺科 } & Muricidae & 珠母爱尔螺 & Ergalatax margariticola & + & & & & & \\
\hline & & 浅缝骨螺 & Murex trapa & + & + & & & & \\
\hline & & 蚛敌荔枝螺 & Thais gradata & + & + & & & & + \\
\hline & & 可变荔枝螺 & Thais mutabilis & + & + & & & & \\
\hline \multirow[t]{5}{*}{ 织纹螺科 } & Nassariidae & 雕刻织纹螺 & Nassarius castus & & + & & & & \\
\hline & & 秀丽织纹螺 & Nassarius festivus & + & + & & & & \\
\hline & & 秀长织纹螺 & Nassarius foveolatus & & + & & & & \\
\hline & & 节织纹螺 & Nassarius nodifer & + & + & & + & & \\
\hline & & 胆形织纹螺 & Nassarius pullus & + & + & & + & & + \\
\hline
\end{tabular}


马维, 王琩, 王文卿, 刘毅, 罗柳青, 唐朝艺. 海南岛西海岸红树林软体动物多样性. 生物多样性, 2018, 26 (7): 707-716. http://www.biodiversity-science.net/CN/10.17520/biods.2018104

\begin{tabular}{|c|c|c|c|c|c|c|c|c|c|}
\hline & & $\begin{array}{l}\text { 中文名 } \\
\text { Chinese name }\end{array}$ & $\begin{array}{l}\text { 学名 } \\
\text { Scientific name }\end{array}$ & $\begin{array}{l}\text { 四必湾 } \\
\text { Sibi Bay }\end{array}$ & $\begin{array}{c}\text { 儋州湾 } \\
\text { Danzhou Bay }\end{array}$ & $\begin{array}{c}\text { 盐丁 } \\
\text { Yanding }\end{array}$ & $\begin{array}{c}\text { 新盈湾 } \\
\text { Xinying Bay }\end{array}$ & $\begin{array}{c}\text { 马售湾 } \\
\text { Maniao Bay }\end{array}$ & $\begin{array}{c}\text { 花场湾 } \\
\text { Huachang Bay }\end{array}$ \\
\hline & & 西格织纹螺 & Nassarius siquijorensis & + & + & & + & & \\
\hline & & 红带织纹螺 & Nassarius succinctus & + & & & & & \\
\hline 头楯目 & Cephalaspidea & & & & & & & & \\
\hline 捻螺科 & Acteonidae & 纵沟蛹螺 & Pupa sulcata & & & + & & & \\
\hline 阿地螺科 & Atyidae & 泥螺 & Bullacta exarata & + & + & & & & + \\
\hline 囊螺科 & Retusidae & 婆罗囊螺 & Retusa borneensis & + & + & & & & \\
\hline 三叉螺科 & Trielidae & 库页球舌螺 & Eocylichna koyasensis & + & + & & & + & + \\
\hline 基眼目 & Basommatophora & & & & & & & & \\
\hline 两栖螺科 & Amphibolidae & 桑切氏两栖螺 & Salinator sanchezi & + & + & & & & \\
\hline \multirow[t]{13}{*}{ 耳螺科 } & Ellobiidae & 双鸟金耳螺 & Auriculastra duplicata & + & & & & & \\
\hline & & 萨克塔金耳螺 & Auriculastra saccata & + & & & & & + \\
\hline & & 细长金耳螺 & Auriculastra subula & & & & & & + \\
\hline & & 伶叟冠耳螺 & Cassidula mustelina & + & & + & & & \\
\hline & & 核冠耳螺 & Cassidula nucleus & + & + & + & & & \\
\hline & & 索冠耳螺 & Cassidula sowerbyana & + & & & & & + \\
\hline & & 犹大耳螺 & Ellobium aurisjudae & + & & + & & & \\
\hline & & 中国耳螺 & Ellobium chinense & + & & & + & & + \\
\hline & & 奥克胁耳螺 & Laemodonta octanfracta & & + & & & + & + \\
\hline & & 美东尖耳螺 & Melampus bidentatus & + & & & & & + \\
\hline & & 暗尖耳螺 & Melampus parvulus & + & & + & & & \\
\hline & & 赛氏女教士螺 & Pythia cecillei & & & & + & & \\
\hline & & 三角女教士螺 & Pythia trigona & & & & & + & + \\
\hline 柄眼目 & Stylommatophora & & & & & & & & \\
\hline 巴蜗牛科 & Bradybaenidae & 扁蜗牛 & Bradybaena similaris & + & & + & & & \\
\hline
\end{tabular}


马维, 王琩, 王文卿, 刘毅, 罗柳青, 唐朝艺. 海南岛西海岸红树林软体动物多样性. 生物多样性, 2018, 26 (7): 707-716. http://www.biodiversity-science.net/CN/10.17520/biods.2018104

\begin{tabular}{|c|c|c|c|c|c|c|c|c|c|}
\hline & & 中文名 & 学名 & 四必湾 & 儋州湾 & 盐丁 & 新盈湾 & 马重湾 & 花场湾 \\
\hline & & Chinese name & Scientific name & Sibi Bay & Danzhou Bay & Yanding & Xinying Bay & Maniao Bay & Huachang Bay \\
\hline 玛瑙螺科 & Achatinidae & 褐云玛瑙螺 & Achatina fulica & + & & & & & + \\
\hline \multirow[t]{2}{*}{ 石磺科 } & Onchidiidae & 瘤背石磺 & Onchidium struma & + & + & & + & & + \\
\hline & & 平疮桑椹石磺 & Platevindex mortoni & & + & & & & \\
\hline
\end{tabular}

